\title{
A Study on the Factors Affecting Satisfaction and Reuse Intention among Customers Using 020 Delivery Platform in China
}

\author{
Yi-bo Zhang, Ha-Kyun Kim \\ Graduate School of Information Systems, Pukyong National University, Korea \\ avery_four@hotmail.com; kimhk@pknu.ac.kr
}

\begin{abstract}
In the early 2020, COVID-19 arrived unexpectedly, and during this epidemic, factories, hotels, and shops were shut down and businesses were hit hard. This has brought serious inconvenience to people's lives. Thanks to the development of mobile technology, more customers choose to order food on delivery platforms compared with in-store. This study takes customers of Onlineto-Offline delivery platform as the research subjects to explore the reasons that affect their customer satisfaction and reuse intention.

This study divides the factors that affect customer satisfaction and reuse intention into two categories, namely, online service quality and offline service quality. Online service quality includes system quality, information quality and customer service quality, while offline service quality includes product quality and delivery quality. Through the online questionnaire survey, 129 out of 153 were collected as valid responses. SPSS22.0 was used to evaluate the quality of the data, and Smart PLS2.0 was used for hypothesis testing. The results of the research are as follows: information quality, customer service quality, product quality and delivery quality has a significant positive impact on customer satisfaction, customer satisfaction has a significant positive impact on reuse intention, and system quality has no positive impact on customer satisfaction.

Based on the research results, this study proposes management implications for Online-to-Offline delivery platforms in the catering industry, so as to improve customers' dining experience and reuse intention, increase customer loyalty, further improve the quality of Online-to-Offline delivery platform, enhance the competitiveness of the platform, and ensure the sustainable development of the Online-to-Offline delivery market.
\end{abstract}

Keywords: $\mathrm{O} 2 \mathrm{O}$ service, $\mathrm{O} 2 \mathrm{O}$ platform, service quality, customer satisfaction, reuse intention. 


\section{Introduction}

The full name of $\mathrm{O} 2 \mathrm{O}$ is Online-to-Offline, which refers to a platform that combines offline business opportunities with the internet, allowing consumers to complete offline transactions through the internet. With the continuous development of mobile internet, big data and other technologies, catering, leisure, entertainment, tourism, education, door-to-door massage, door-to-door makeup, DiDi taxi, and $\mathrm{O} 2 \mathrm{O}$ has swept various industries in China where catering is a huge branch of the O2O industry. In 2019 the total revenue of Chinese catering market was 4672.1 billion yuan, and the transaction volume of delivery platforms represented by MeiTuan and ELeMe was 653.5 billion yuan. Affected by the epidemic in 2020, with the total revenue of the catering industry decreasing, the proportion of distribution platform transactions has steadily increased, reaching a staggering $26 \%$ (China Catering Big Data, 2020).

Due to the unlimited development prospects of the $\mathrm{O} 2 \mathrm{O}$ market and the emergence of various capital markets involved in the industry, competition among major platforms is fierce, and they have begun to fight price wars and give preferential strategies. However, due to the country's insufficient protection of consumer rights and interests, there are problems such as platform false propaganda, untimely delivery of meals, and non-compliant food hygiene standards of merchants. Therefore, it is proposed whether $\mathrm{O} 2 \mathrm{O}$ online service quality and offline service quality will significantly affect consumer satisfaction and reuse intention issues.

This study combines the characteristics of $\mathrm{O} 2 \mathrm{O}$ delivery and divides the factors that affect customer satisfaction and reuse intention into two aspects: online service quality and offline service quality. Online service quality is split into system quality, information quality and customer service quality, while offline service quality is split into product quality and delivery quality, which are used as independent variables. Reuse intentions are set at the same time to construct a research model of factors affecting consumer reuse intentions of $\mathrm{O} 2 \mathrm{O}$ delivery platform put forward hypotheses and pass questionnaire surveys after obtaining the data, use SPSS22.0 to evaluate the data quality, and then use Smart PLS 2.0 to perform hypothesis testing, so as to obtain the factors that really affect the customer satisfaction and reuse intention of the delivery platform, which is very important for the $\mathrm{O} 2 \mathrm{O}$ delivery platform and operation of the catering industry. According to the research results, this paper puts forward management inspiration for $\mathrm{O} 2 \mathrm{O}$ delivery platforms in catering industry to improve customers' reuse intentions, increase customer loyalty, and further enhance the competitiveness of the platform to ensure the sustainable development of the $\mathrm{O} 2 \mathrm{O}$ delivery market.

The innovation of this study is to introduce service quality in the field of $\mathrm{O} 2 \mathrm{O}$ delivery, and combines the characteristics of delivery to divide the $\mathrm{O} 2 \mathrm{O}$ delivery service into two parts: online service quality and offline service quality, and establish a new model frame to verify the impact, factors influencing customers' 
intention to reuse and their suitability in the delivery sector.

\section{Theoretical Background}

\subsection{O2O Service and Platform}

$\mathrm{O} 2 \mathrm{O}$, or online-to-offline, was first proposed by the founder and CEO of TRIALPAY - ALEX RAMPEL in 2010. He pointed out that O2O is a way to create traffic by finding consumers on the Internet and then bringing them to physical stores. However, it has not given a clear concept, so there are many definitions (Sun and Lee, 2014). In a broad sense, $\mathrm{O} 2 \mathrm{O}$ is defined as the procurement activities that combine Online and Offline and can influence each other. Therefore, there are various modes, such as Online to Offline, Online to Offline, Offline to Offline, and Offline to Offline.

The $\mathrm{O} 2 \mathrm{O}$ concept that appears in this research is the first one, namely online merchant transactions - offline consumer experience, which can be understood as the $\mathrm{O} 2 \mathrm{O}$ platform helps merchants to promote online, acting as a showcase, facilitating transactions, and then allowing users to enjoy products and services offline, while the platform charges promotion fees, and commissions are drawn from merchants based on transaction volume (Kim, 2020). A typical representative is $\mathrm{O} 2 \mathrm{O}$ delivery platform. Consumers can order food through the delivery platform, and can also purchase and pay within the platform, and even the platform can make purchases on behalf of customers. The $\mathrm{O} 2 \mathrm{O}$ delivery platform builds a bridge between offline suppliers and consumers, provides suppliers with a large number of effective promotions for a restaurant with insufficient awareness in a short time and at a lower cost, and provides consumers with Ordering and experience of goods that were previously only accessible offline, saving consumers time and travel expenses (Jung, 2016).

With the outbreak of the COVID-19, people's non-face-to-face life began. This method of delivery is safer and does not even require direct contact with delivery personnel. It is obviously more advantageous, which greatly increases the utilization rate of $\mathrm{O} 2 \mathrm{O}$ delivery platforms.

\subsection{Service Quality}

The study of service quality began in 1970. It is the sum of the characteristics and features of a product produced by a service or service industry that meet specific or potential requirements. Characteristics are the concepts used to distinguish different types of products or services, while features are the concepts used to distinguish different specifications, grades and tastes in similar services. The apparent connotation of service quality should include the general requirements of safety, suitability, effectiveness and economy of the service (Hu et al., 2021).

The customer compares the expected service quality of the company with the perceived service quality and thus considers the company's service quality as higher 
or lower. This is a subjective evaluation of the service quality by the customer, which not only considers the result of the service but also involves the process of the service. The expected service quality is the customer's expected satisfaction with the service provided by the service company, while the perceived service quality is the actual level of customer perception of the service provided by the service company. Therefore, service quality is the key to the success of the company and is considered to be an important factor influencing customer satisfaction with the 020 service platform (Jin et al., 2020).

According to the features of service quality, this paper divides service quality into online service quality and offline service quality.

\subsection{Online Service Quality}

Santos defined online service quality as the overall perception, evaluation, and judgment of customers obtaining services from virtual spaces. It is developed and evolved on the basis of traditional service quality, unlike the offline concept, where the user does not need to contact the merchant that provides the service. That is, the quality of service provided by mobile phones or computers in the network environment, so it is also defined as the quality of service through electronic networks in a broad sense. With the popularization of Internet information technology, the development trend of electronic network services has further accelerated, online service quality has become one of the important factors of service quality, because online services have surpassed offline services and become the most important means of interaction between merchants and consumers (Santos, 2003). Therefore, more scholars began to pay attention to the research of online service quality.

Based on the analysis results of previous studies, in this study, combined with online service quality characteristics, system quality, information quality and customer service quality are selected as important factors affecting customer satisfaction on $\mathrm{O} 2 \mathrm{O}$ delivery platforms.

\subsubsection{System quality}

System quality means that while providing services to users, they can use the system easily, conveniently and safely without technical problems. The survey shows that when a customer encounters a system quality problem when using a specific system, such as slow page conversation speed or frequent disconnection, it will cause the user to stop using it instead of asking for correction or complaining (Choi and Choi, 2011). The main considerations in this article are safety, convenience, and ease of use. The delivery platforms all use smart phones or PCs as carriers, so in this study, system quality was selected as one of the important variables. 


\subsubsection{Information quality}

Information quality refers to the quality of information and content. It usually refers to the level of consumer use of information provided by the information system. It is an important factor influencing consumer behavior or purchasing decisions. In the network environment, consumers evaluate the quality of information based on the quantity, accuracy, reliability, timeliness and objectivity of product information (Jeon et al., 2019). The research results show that information quality plays an important role in determining the perceived benefits of information system use, business profitability, system use level and user satisfaction. Through the evaluation of information quality, sufficient information is provided in the right place, with the amount of information that meets expectations, consumer will have a positive perception of the quality of the information. The $\mathrm{O} 2 \mathrm{O}$ delivery platform serves as a transmitter of information between merchants and consumers, the quality of information directly determines the consumer's consumption behavior or purchase decision (Zhang et al., 2021). Therefore, this study chose it as one of the important variables.

\subsubsection{Customer service quality}

Service quality refers to the degree of conformity between the provided service and customer expectations. The broad service quality includes employee quality, order quality, delivery quality, and product status. The service quality discussed in this research refers to the service quality of platform customer service personnel. When customers encounter problems online, if they need to consult products and services, the first to contact is online customer service. It is a service that exists to meet customer expectations, and thus, service quality is directly determined by customer satisfaction (Lewis and Booms, 1983). Excellent customer service requires not only professional knowledge, but also the ability to solve problems and complaints, adaptability, high tolerance and good communication skills. More and more companies are beginning to improve the quality of customer service. So this study chose it as one of the important variables.

\subsection{Offline Service Quality}

Before the Internet was popularized, most of the company's business activities were based on traditional models, that is, all business activities were based on stores. In offline services, the criteria for consumers to choose stores first varies from researcher to researcher, but product, service and location factors are the most important factors. Most of the reasons for choosing offline services instead of online services are uncertainty avoidance and shopping experience, especially the actual product is relatively low compared to the value of payment. The quality of these services is defined as service quality. According to the analysis results of previous studies, traditional service quality is the foundation of online service quality (Park and $\mathrm{Ha}, 2012$ ). In the transaction process, the perceived value and satisfaction of 
consumers depend on the quality of offline services. In this study, combining the characteristics of offline services, product quality and delivery quality are selected as important factors affecting customer satisfaction on $\mathrm{O} 2 \mathrm{O}$ delivery platforms.

\subsubsection{Product quality}

Product quality is defined by many scholars in various forms. Generally, it refers to the essential quality and appearance of a commodity, including both subjective and objective elements. However, quality must satisfy consumers' perceptions, desires and purposes through products. Therefore, it is necessary to understand this concept with consumers as the center. The conclusion of the study is that the six basic elements of product quality are: taste, appearance, and quantity, hygiene, packaging and free ingredients (Yang, 2019). In the research of product quality and satisfaction, product quality is one of the most influential basic factors (Wu, 2020). Since the distribution service is to provide food to consumers, the quality of the product must become the primary consideration, so this study chose it as one of the important variables.

\subsubsection{Delivery quality}

Delivery is a form of service in which the seller or delivery person delivers the food or ingredients to the place requested by the consumer. Delivery quality means that when a consumer places an order through the system, the merchant confirms the content of the order, prepares the food, and then delivers it to a series of service quality at the location designated by the consumer (Lee, 2019). In recent years, with the continuous improvement of service quality, the competition for delivery quality has become more and more fierce. Catering companies are seeking personalized and differentiated delivery services for products and consumer needs, and they are developing rapidly. Delivery quality is a basic management strategy that enterprises should consider when providing delivery services to consumers. Because consumers' satisfaction after experiencing delivery services will directly affect the satisfaction of the entire service experience, the $\mathrm{O} 2 \mathrm{O}$ distribution platform will further increase the requirements for distribution quality, but it is also necessary to understand the factors that affect the quality of consumer services (Lee et al., 2019). Since delivery service is not only a competition for delivery speed, but also increased reliability, information and security, therefore, this study chose the delivery quality as one of the important variables.

\subsection{Customer Satisfaction}

Customer satisfaction, also known as customer satisfaction index, is the abbreviation of customer satisfaction survey system in the service industry. It is the degree of match between customer expectation and customer experience, that is to say, customers can perceive the product through the index, the effect obtained by comparing with its expected value, which was first introduced into the marketing 
field by CAEDOZO (Oliver, 1981). Generally, if the service quality experienced by consumers is higher than expected, the satisfaction is high, if it is lower than expected, then they are dissatisfied, and if the value is the same as expected, both satisfaction and dissatisfaction are possible. Therefore, in order to improve the service quality of the company to be certified by customers, it is necessary to provide consumers with higher-than-expected service quality. Research data shows that if customers are dissatisfied with the service and do not get satisfactory results, customers with low satisfaction will give up using or buy back, and may even make negative comments (Park et al., 2021).

\subsection{Reuse Intention}

Reuse intention is an intensity of the intention to continue using or repurchase the product or service upon receipt of the product or service. It refers to the possibility that attitudes and beliefs about a particular product or service can be translated into actual behavior. By comparing the perceived performance of a product with the consumer's expectations before purchasing the product or service, the customer feels dissatisfied or satisfied. Through this process, the customer decides whether to reuse or repurchase the product or service. Expected benefits play an important role in the formation of the willingness to reuse intention. The study found that customer satisfaction with products on delivery platforms had a positive impact on reuse or repurchase intention (Engel and Blackwell, 1982).

\section{Research Methods}

\subsection{Research Model}

The purpose of this research is to derive a research model based on theoretical research and discuss the operational definition and research methods of variables.

In this research, the influencing factors of the research are confirmed by combining the relevant theories, the practicality of the research and the purpose of the research. Combining the characteristics of $\mathrm{O} 2 \mathrm{O}$ delivery platform, the service quality is divided into online service quality and offline service quality. The online service quality is divided into system quality, information quality and customer service quality, while offline service quality is divided into product quality and delivery quality, using them as independent variables, and setting customer satisfaction and reuse intention at the same time, constructing a research model of the factors affecting the reuse intention of consumers on the $\mathrm{O} 2 \mathrm{O}$ delivery platform. The research model is shown in Fig. 1.

\subsection{Research Hypotheses}

Through previous research, it can be confirmed that system quality, information quality, customer service quality, product quality, and delivery quality have a significant impact on customer satisfaction, and customer satisfaction has a 
significant impact on reuse intention, so the following hypotheses are established:

H1-1-System quality has a positive impact on customer satisfaction

H1-2 - Information quality has a positive impact on customer satisfaction

H1-3 - Customer service quality has a positive impact on customer satisfaction

$\mathrm{H} 2-1$ - Product quality has a positive impact on customer satisfaction

H2-2 - Delivery quality has a positive impact on customer satisfaction

H3 - Customer satisfaction has a positive effect on reuse intention

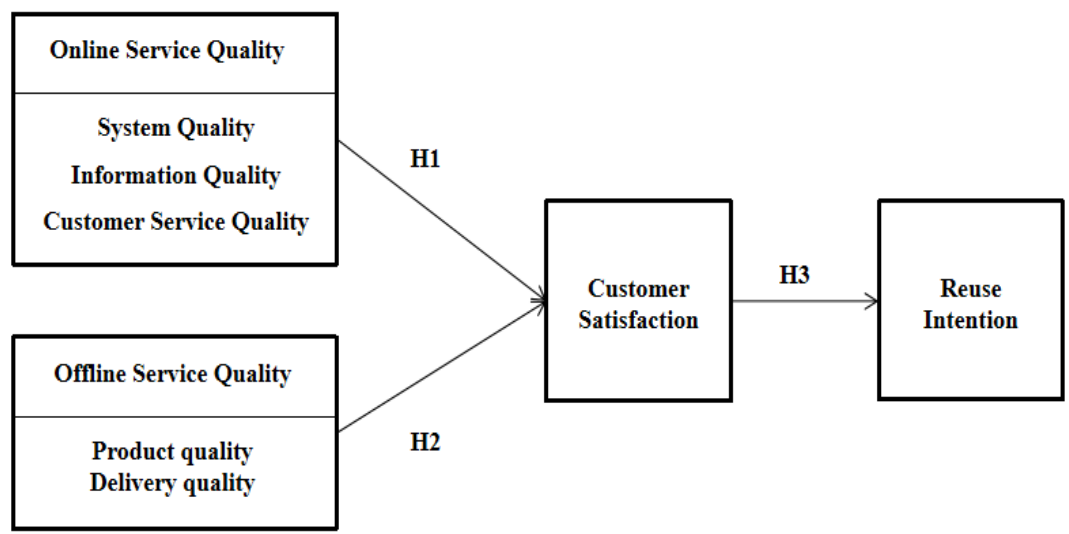

Fig. 1: Research model.

\subsection{Operational Definition of Variables}

The operational definition of the variables used in this study are shown in Table 1.

Table 1: Operational definition

\begin{tabular}{|c|c|c|}
\hline Variable name & Operational definition & References \\
\hline Service quality & $\begin{array}{l}\text { Service quality is the sum of the characteristics and } \\
\text { characteristics of the products produced by the service or } \\
\text { the service industry that meet the prescribed or potential } \\
\text { requirements. }\end{array}$ & $\begin{array}{l}\text { Hu et al., } \\
2021\end{array}$ \\
\hline $\begin{array}{l}\text { Online service } \\
\text { quality }\end{array}$ & $\begin{array}{l}\text { Online service quality as the overall perception, } \\
\text { evaluation, and judgment of customers obtaining services } \\
\text { from virtual spaces. }\end{array}$ & $\begin{array}{l}\text { Santos, } \\
2003\end{array}$ \\
\hline System quality & $\begin{array}{l}\text { System quality means that while providing services to } \\
\text { users, they can use the system easily, conveniently and } \\
\text { safely without technical problems. }\end{array}$ & $\begin{array}{l}\text { Choi and } \\
\text { Choi, } 2011\end{array}$ \\
\hline $\begin{array}{l}\text { Information } \\
\text { quality }\end{array}$ & $\begin{array}{l}\text { Information quality refers to the quality of information and } \\
\text { content. It usually refers to the level of consumer use of } \\
\text { information provided by the information system. }\end{array}$ & $\begin{array}{l}\text { Jeon et al., } \\
2019\end{array}$ \\
\hline $\begin{array}{l}\text { Customer } \\
\text { service quality }\end{array}$ & $\begin{array}{l}\text { The service quality discussed in this research refers to the } \\
\text { service quality of platform customer service personnel. }\end{array}$ & $\begin{array}{c}\text { Lewis and } \\
\text { Booms, } \\
1983\end{array}$ \\
\hline
\end{tabular}




\begin{tabular}{|c|c|c|c|}
\hline $\begin{array}{c}\text { Offline service } \\
\text { quality }\end{array}$ & $\begin{array}{c}\text { Before the internet was popularized, most of the } \\
\text { company's business activities were based on traditional } \\
\text { models, that is, all business activities were based on stores. } \\
\text { The quality of these services is defined as service quality. }\end{array}$ & Park and \\
\hline Product quality & $\begin{array}{c}\text { Product quality refers to the essential quality and } \\
\text { appearance of a commodity, including both subjective and } \\
\text { objective elements. }\end{array}$ & Yang, 2019 \\
\hline Delivery quality & $\begin{array}{c}\text { Delivery quality means that when a customer places an } \\
\text { order through the system, the merchant confirms the } \\
\text { content of the order, prepares the food, and then delivers it } \\
\text { to a series of service quality at the location designated by } \\
\text { the customer. }\end{array}$ & Lee, 2019 \\
\hline Customer & $\begin{array}{c}\text { Customer satisfaction, also known as customer satisfaction } \\
\text { index, is the abbreviation of the customer satisfaction } \\
\text { survey system in the service industry. }\end{array}$ & Oliver, \\
\hline Reuse intention & $\begin{array}{c}\text { Reuse intention is the intensity of the intention to continue } \\
\text { using or repurchase the product or service upon receipt of } \\
\text { the product or service. This refers to the possibility that } \\
\text { attitudes and beliefs about a particular product or service } \\
\text { can be translated into actual behavior. }\end{array}$ & $\begin{array}{c}\text { Engel and } \\
\text { Blackwell, } \\
1982\end{array}$ \\
\hline
\end{tabular}

\subsection{Questionnaire Survey Design}

This study conducted a survey in the form of online questionnaires and collected a total of 153 online questionnaires. The 16 questionnaires that have not used the delivery platform were excluded, and in order to ensure the reliability of the questionnaire survey, we checked the questionnaires with the same score consecutively as invalid questionnaires and removed them. In the end, 129 valid online questionnaires were successfully collected. The following describes the demographic characteristics of the subjects.

Table 2: Demographic characteristics

\begin{tabular}{|c|c|c|c|}
\hline \multicolumn{2}{|c|}{ Item } & Frequency & Percent \\
\hline \multirow{3}{*}{ Gender } & Male & 41 & $31.8 \%$ \\
\cline { 2 - 4 } & Female & 88 & $68.2 \%$ \\
\hline \multirow{3}{*}{ Age } & Under 20 & 39 & $30.2 \%$ \\
\cline { 2 - 4 } & $20-29$ & 53 & $41.1 \%$ \\
\cline { 2 - 4 } & $30-39$ & 26 & $20.2 \%$ \\
\cline { 2 - 4 } & Over 40 & 11 & $8.5 \%$ \\
\hline \multirow{3}{*}{ Education } & College degree and below & 41 & $31.8 \%$ \\
\cline { 2 - 4 } & regular college course & 60 & $46.5 \%$ \\
\cline { 2 - 4 } & Master degree or above & 28 & $21.7 \%$ \\
\hline
\end{tabular}




\begin{tabular}{|c|c|c|c|}
\hline \multirow{3}{*}{$\begin{array}{c}\text { Weekly } \\
\text { Frequency }\end{array}$} & within 1 time & 68 & $52.7 \%$ \\
\cline { 2 - 4 } & within 1-3 times & 42 & $32.6 \%$ \\
\cline { 2 - 4 } & within 4-6 times & 8 & $6.2 \%$ \\
\cline { 2 - 4 } & 7 times or more & 11 & $8.5 \%$ \\
\hline
\end{tabular}

This research analyzes the reuse intention of $\mathrm{O} 2 \mathrm{O}$ consumers based on the theoretical model. The model sets a total of seven variables, including system quality, information quality, customer service quality, product quality, delivery quality, customer satisfaction, and reuse intention. Each latent variable corresponds to three or four observation indicators, and each indicator uses a five-point LIKER scale to expand the measurement, that is, completely disagree to completely agree with five options, corresponding to one to five points respectively. The measurement scale is shown in Table 3.

Table 3: Metrics by variable

\begin{tabular}{|c|c|c|}
\hline $\begin{array}{l}\text { Variable } \\
\text { name }\end{array}$ & Detail & $\begin{array}{c}\text { Prior } \\
\text { Research }\end{array}$ \\
\hline \multirow{3}{*}{$\begin{array}{l}\text { System } \\
\text { quality }\end{array}$} & The response speed of the selling platform is fast & \multirow{3}{*}{$\begin{array}{l}\text { Jeon et al., } \\
\quad 2019\end{array}$} \\
\hline & The platform has many functions and is convenient to use & \\
\hline & $\begin{array}{l}\text { Selling in the platform program system is safe and not prone to } \\
\text { crashes and other issues }\end{array}$ & \\
\hline \multirow{3}{*}{$\begin{array}{l}\text { Informatio } \\
\text { n quality }\end{array}$} & $\begin{array}{l}\text { There are many business information released by the selling } \\
\text { platform, and there are many kinds of dishes }\end{array}$ & \multirow{3}{*}{ Lee, 2019} \\
\hline & $\begin{array}{l}\text { The merchant information and dishes released by the selling } \\
\text { platform are consistent with the actual situation }\end{array}$ & \\
\hline & The information of the selling platform is updated quickly & \\
\hline \multirow{3}{*}{$\begin{array}{c}\text { Customer } \\
\text { service } \\
\text { quality }\end{array}$} & $\begin{array}{l}\text { The selling platform will recommend meals that may be of } \\
\text { interest to me }\end{array}$ & \multirow{3}{*}{$\begin{array}{l}\text { Lee et al., } \\
2019\end{array}$} \\
\hline & $\begin{array}{l}\text { The staff of the selling platform will deal with my complaints, } \\
\text { refunds and other issues in a timely manner }\end{array}$ & \\
\hline & The customer service staff of the selling platform are friendly & \\
\hline \multirow{4}{*}{$\begin{array}{l}\text { Product } \\
\text { quality }\end{array}$} & $\begin{array}{l}\text { The meals provided by the sellers on the platform are clean and } \\
\text { hygienic, and taste delicious }\end{array}$ & \multirow{4}{*}{$\begin{array}{l}\text { Lee et al., } \\
2019\end{array}$} \\
\hline & $\begin{array}{l}\text { The sellers on the platform provide better packaging to maintain } \\
\text { the appearance and freshness of meals }\end{array}$ & \\
\hline & $\begin{array}{l}\text { The sellers on the platform will prepare meals within the } \\
\text { promised time }\end{array}$ & \\
\hline & $\begin{array}{l}\text { The seller of the platform will prepare meals according to the } \\
\text { requirements of the remarks }\end{array}$ & \\
\hline
\end{tabular}




\begin{tabular}{|c|c|c|}
\hline \multirow{4}{*}{$\begin{array}{l}\text { Delivery } \\
\text { quality }\end{array}$} & $\begin{array}{l}\text { The service attitude of the distribution staff of the selling } \\
\text { platform is friendly }\end{array}$ & \multirow{4}{*}{ Lee, 2019} \\
\hline & $\begin{array}{l}\text { The distribution staff of the selling platform can deliver the } \\
\text { exact order quantity of meals }\end{array}$ & \\
\hline & $\begin{array}{l}\text { The delivery personnel of the selling platform can deliver meals } \\
\text { within the promised time }\end{array}$ & \\
\hline & $\begin{array}{l}\text { The distribution staff of the selling platform will deliver the } \\
\text { meals according to the remarks }\end{array}$ & \\
\hline \multirow{3}{*}{$\begin{array}{l}\text { Customer } \\
\text { satisfaction }\end{array}$} & The selling platform can meet my ordering needs & \multirow{3}{*}{ Lee, 2019} \\
\hline & $\begin{array}{l}\text { It is a wise decision to order food using the external selling } \\
\text { platform (compared to other platforms) }\end{array}$ & \\
\hline & $\begin{array}{l}\text { I am generally satisfied with the overall feeling of the external } \\
\text { platform }\end{array}$ & \\
\hline \multirow{3}{*}{$\begin{array}{l}\text { Reuse } \\
\text { intention }\end{array}$} & $\begin{array}{l}\text { I will choose to sell platforms outside, even if other platforms } \\
\text { appear }\end{array}$ & \multirow{3}{*}{$\begin{array}{l}\text { Jeon et al., } \\
2019\end{array}$} \\
\hline & I would like to recommend other selling platforms to others & \\
\hline & I will continue to use the other selling platform to order food & \\
\hline
\end{tabular}

\section{Empirical Analysis}

\subsection{Effectiveness and Reliability of Measurement Tools}

Reliability analysis was performed to test whether there was internal consistency among the observed indicators of each subscale. The value of Cronbach's $\alpha$ was used as the test of internal consistency of each subscale. In general, the combined value of the elements is above 0.6 , the value of the compositional reliability is above 0.7 , and the value of the variance extraction index is above 0.5 . The square root of the variance extraction index value compared with the correlation coefficient resulted in the variance extraction index value being greater than the longitudinal correlation coefficient value, so there was no problem with discriminant validity. The findings are presented in tables 4 and 5 .

\subsection{Test Hypothesis}

Compared with structural equations, the advantage of PLS analysis is that it can use a smaller number of samples for analysis, because it can use 10 times the maximum number of observations for each latent variable for analysis. Therefore, in this research, taking into account the theoretical stability, sample size and other characteristics, Smart PLS is used as the data analysis method. If the R2 value is 0.26 or more, the suitability is "high", if it is 0.26 to 0.13 , the suitability is "medium", and if it is less than 0.13, the suitability is "low" (Cohen, 1988).

As shown in Figure 2, the customer satisfaction CS (0.596) and reuse intention 
(0.356) in this study were evaluated as "good".

Table 4: Reliability and internal consistency

\begin{tabular}{|c|c|c|c|c|c|}
\hline \multicolumn{2}{|c|}{ Variable } & $\begin{array}{l}\text { Factor } \\
\text { loading }\end{array}$ & $\begin{array}{l}\text { Composite } \\
\text { Reliability }\end{array}$ & AVE & $\begin{array}{c}\text { Cronbach's } \\
\text { Alpha }\end{array}$ \\
\hline \multirow{3}{*}{$\begin{array}{l}\text { System } \\
\text { Quality }\end{array}$} & SQ1 & 0.670 & \multirow{3}{*}{0.799} & \multirow{3}{*}{0.572} & \multirow{3}{*}{0.627} \\
\hline & SQ2 & 0.850 & & & \\
\hline & SQ3 & 0.738 & & & \\
\hline \multirow{3}{*}{$\begin{array}{l}\text { Informatio } \\
\text { n Quality }\end{array}$} & IQ1 & 0.803 & \multirow{3}{*}{0.850} & \multirow{3}{*}{0.655} & \multirow{3}{*}{0.736} \\
\hline & IQ2 & 0.782 & & & \\
\hline & IQ3 & 0.841 & & & \\
\hline \multirow{3}{*}{$\begin{array}{c}\text { Customer } \\
\text { Service } \\
\text { Quality }\end{array}$} & CSQ1 & 0.660 & \multirow{3}{*}{0.826} & \multirow{3}{*}{0.616} & \multirow{3}{*}{0.684} \\
\hline & CSQ2 & 0.799 & & & \\
\hline & CSQ3 & 0.880 & & & \\
\hline \multirow{4}{*}{$\begin{array}{l}\text { Product } \\
\text { Quality }\end{array}$} & PQ1 & 0.775 & \multirow{4}{*}{0.858} & \multirow{4}{*}{0.602} & \multirow{4}{*}{0.780} \\
\hline & PQ2 & 0.797 & & & \\
\hline & PQ3 & 0.738 & & & \\
\hline & PQ4 & 0.792 & & & \\
\hline \multirow{4}{*}{$\begin{array}{c}\text { Delivery } \\
\text { Quality }\end{array}$} & DQ1 & 0.775 & \multirow{4}{*}{0.865} & \multirow{4}{*}{0.616} & \multirow{4}{*}{0.792} \\
\hline & DQ2 & 0.794 & & & \\
\hline & DQ3 & 0.712 & & & \\
\hline & DQ4 & 0.852 & & & \\
\hline \multirow{3}{*}{$\begin{array}{c}\text { Customer } \\
\text { Satisfactio } \\
n\end{array}$} & CS1 & 0.788 & \multirow{3}{*}{0.850} & \multirow{3}{*}{0.654} & \multirow{3}{*}{0.735} \\
\hline & $\mathrm{CS} 2$ & 0.796 & & & \\
\hline & $\mathrm{CS} 3$ & 0.840 & & & \\
\hline \multirow{3}{*}{$\begin{array}{c}\text { Reuse } \\
\text { Intention }\end{array}$} & RI1 & 0.832 & \multirow{3}{*}{0.849} & \multirow{3}{*}{0.653} & \multirow{3}{*}{0.734} \\
\hline & RI2 & 0.787 & & & \\
\hline & RI3 & 0.804 & & & \\
\hline
\end{tabular}

Table 5: Correlation and Discriminant Validity

\begin{tabular}{|c|c|c|c|c|c|c|c|c|}
\hline Variable & AVE & SQ & IQ & CSQ & PQ & DQ & CS & RI \\
\hline System Quality & 0.572 & 0.755 & & & & & & \\
\hline $\begin{array}{c}\text { Information } \\
\text { Quality }\end{array}$ & 0.655 & 0.532 & 0.808 & & & & & \\
\hline $\begin{array}{c}\text { Customer } \\
\text { Service Quality }\end{array}$ & 0.616 & 0.438 & 0.646 & 0.784 & & & & \\
\hline Product Quality & 0.602 & 0.415 & 0.618 & 0.645 & 0.775 & & & \\
\hline Delivery Quality & 0.616 & 0.495 & 0.524 & 0.501 & 0.625 & 0.784 & & \\
\hline $\begin{array}{c}\text { Customer } \\
\text { Satisfaction }\end{array}$ & 0.654 & 0.484 & 0.615 & 0.619 & 0.654 & 0.663 & 0.808 & \\
\hline Reuse Intention & 0.653 & 0.341 & 0.580 & 0.535 & 0.467 & 0.463 & 0.596 & 0.807 \\
\hline
\end{tabular}




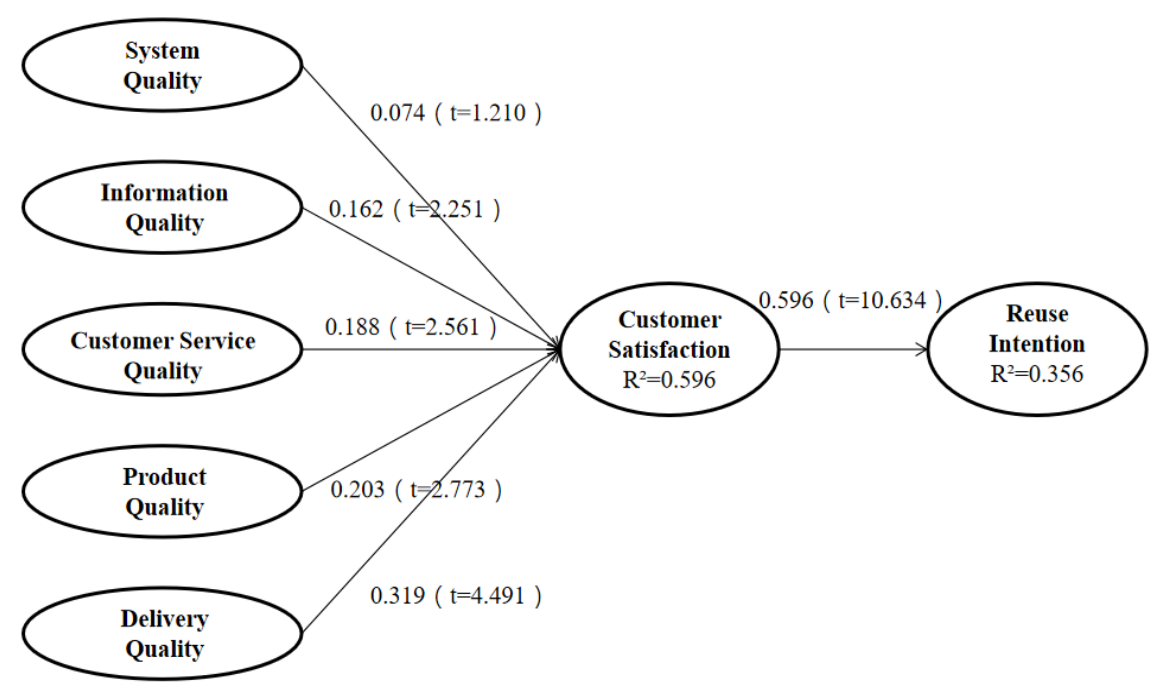

Fig. 2: Results of research model.

\subsection{Analysis of Test Results}

This study uses the CR statistic ( $t$ value) as the basis for the validity of the test. If the absolute value of the critical ratio of the CR test statistic is greater than 1.96, it indicates that the path relationship corresponding to the test statistic reaches the 0.05 significance test probability value. The corresponding path relationship in the structural equation model is retained, and the corresponding assumption is established. If the absolute value of the CR test statistic is greater than 1.96, indicating that the path relationship used by the test statistic does not reach the 0.05 significance test probability value, the corresponding path relationship in the structural equation model is deleted, and the corresponding hypothesis is invalid. The results of the study are as follows.

Hypothesis H1-1: "System quality (SQ) has a positive effect on customer satisfaction (CS)" is statistically significant at a significance level of 95\% (H1-1; $\beta$ $=0.074, \mathrm{t}=1.210$ ), therefore, the hypothesis H1-1 was rejected.

Hypothesis H1-2: "Information quality (IQ) has a positive effect on customer satisfaction (CS)" is statistically significant at a significance level of 95\% (H1-2; $\beta$ $=0.162, \mathrm{t}=2.251$ ), therefore, the hypothesis H1-2 was supported.

Hypothesis H1-3: "Customer service quality (CSQ) has a positive effect on customer satisfaction (CS)" is statistically significant at a significance level of $95 \%$ (H1-3; $\beta=0.188, \mathrm{t}=2.561)$, therefore, the hypothesis H1-3 was supported.

Hypothesis H2-1: "Product quality (PQ) has a positive effect on customer satisfaction (CS)" is statistically significant at a significance level of 95\% (H2-1; $\beta$ $=0.203, \mathrm{t}=2.773$ ), therefore, the hypothesis $\mathrm{H} 2-1$ was supported.

Hypothesis H2-2: "Delivery quality (DQ) has a positive effect on customer satisfaction (CS)" is statistically significant at a significance level of 95\% (H2-2; $\beta$ 
$=0.319, \mathrm{t}=4.491)$, therefore, the hypothesis $\mathrm{H} 2-2$ was supported.

Hypothesis H3: "Customer satisfaction (CS) has a positive effect on reuse intention (RI)" is statistically significant at a significance level of 95\% (H3; $\beta=$ $0.596, \mathrm{t}=10.634)$, therefore, the hypothesis $\mathrm{H} 3$ was supported.

The results are shown in Table 6.

Table 6: Hypothesis test result summary

\begin{tabular}{|c|c|c|c|c|c|}
\hline Hypothesis & cause variable & result variable & $\begin{array}{c}\text { path } \\
\text { coefficient }\end{array}$ & t-value & result \\
\hline H1-1 & System Quality & $\begin{array}{c}\text { Customer } \\
\text { Satisfaction } \\
\end{array}$ & 0.074 & 1.210 & Rejected \\
\hline $\mathrm{H} 1-2$ & $\begin{array}{c}\text { Information } \\
\text { Quality } \\
\end{array}$ & $\begin{array}{c}\text { Customer } \\
\text { Satisfaction }\end{array}$ & 0.162 & 2.251 & Supported \\
\hline $\mathrm{H} 1-3$ & $\begin{array}{c}\text { Customer } \\
\text { Service Quality }\end{array}$ & $\begin{array}{c}\text { Customer } \\
\text { Satisfaction }\end{array}$ & 0.188 & 2.561 & Supported \\
\hline $\mathrm{H} 2-1$ & Product Quality & $\begin{array}{c}\text { Customer } \\
\text { Satisfaction }\end{array}$ & 0.203 & 2.773 & Supported \\
\hline $\mathrm{H} 2-2$ & $\begin{array}{c}\text { Delivery } \\
\text { Quality }\end{array}$ & $\begin{array}{c}\text { Customer } \\
\text { Satisfaction }\end{array}$ & 0.319 & 4.491 & Supported \\
\hline $\mathrm{H} 3$ & $\begin{array}{l}\text { Customer } \\
\text { Satisfaction }\end{array}$ & Reuse Intention & 0.596 & 10.634 & Supported \\
\hline \multicolumn{6}{|c|}{$t=1.960 * *(p<0.05)$} \\
\hline
\end{tabular}

\section{Conclusion}

In this study, $\mathrm{O} 2 \mathrm{O}$ delivery service quality is divided into online and offline. Online service quality is divided into system quality, information quality and customer service quality. Offline service quality is divided into product quality and delivery quality, and service quality. These were combine with customer satisfaction and reuse intentions to build a model and propose the hypotheses. Among them, "H1-1 System quality (SQ) has a positive effect on customer satisfaction (CS)" is not established, "H1-2 Information quality (IQ) has a positive effect on customer satisfaction (CS)", "H1-3 Customer service quality (CSQ) has a positive effect on customer satisfaction (CS)", "H2-1 Product quality (PQ) has a positive effect on customer satisfaction (CS)", "H2-2 Delivery quality (DQ) has a positive effect on customer satisfaction (CS)" and "H3 Customer satisfaction (CS) has a positive effect on reuse intention (RI)" were established.

The study found that information quality, customer service quality, product quality, and delivery quality have a significant positive impact on customer satisfaction. Among them, delivery quality has the largest and strongest influence on $\mathrm{O} 2 \mathrm{O}$ customer satisfaction, followed by product quality, third is the quality of customer service, and finally the quality of information. From this, it can be inferred 
that consumer satisfaction is directly related to delivery quality and product quality. Therefore, a good market not only requires the $\mathrm{O} 2 \mathrm{O}$ platform to do a good job in ordering, recommendation, process tracking, customer complaints and refunds. For the above problem, it is necessary to improve the safety level of offline meals, the level of packaging, the speed of preparing meals, the preparation of meals according to customer requirements and other services, as well as the speed of delivery, the quality of delivery personnel, and the delivery of services in accordance with the requirements of the customers.

The research results show that the quality of the system does not have a significant impact on the satisfaction of customers. The analysis may be due to the rapid development of network technology and the popularization of 5G networks. Customers pay relatively little attention to the quality of the selling platform system, resulting in the system quality not having a significant positive impact on customer satisfaction.

At the same time, in the research results, $\mathrm{O} 2 \mathrm{O}$ platform consumer satisfaction has a significant impact on willingness to reuse, and it is also the variable with the highest total effect value. The reason for the analysis may be that the respondents confuse the willingness to reuse the "food delivery platform in use" with the willingness to reuse the "order food delivery", resulting in a high total effect of consumer satisfaction on the willingness to reuse.

Empirical research shows that increasing O2O consumers' satisfaction has a significant impact on increasing reuse intentions. Platforms should focus on improving the product quality and delivery quality of merchants while providing other services. This leads to the following four suggestions.

First of all, it is recommended that the $\mathrm{O} 2 \mathrm{O}$ platform improve and regulate the quality of delivery personnel, shorten delivery time and try to meet customer remarks requirements. Second, it is suggested that the $\mathrm{O} 2 \mathrm{O}$ takeout platform should improve the entry review conditions of merchants and implement a reward and punishment mechanism for model merchants: certain rewards should be given to high-quality merchants with high product quality and service according to the remarks of consumers, and the cooperative relationship should be terminated with merchants with poor product quality, etc. Third, improve the complaint mechanism for consumers, handle consumer complaints in a timely manner, and maintain a good order in the market. Finally, this survey shows that the vast majority of respondents order through mobile apps, and the respondents are mainly female customers under the age of 40. The platform can increase advertising efforts for this audience group, cultivate customer consumption habits, and increase customer loyalty.

This article mainly analyzes consumers' willingness to reuse from the perspective of $\mathrm{O} 2 \mathrm{O}$ delivery platform quality and customer satisfaction, but there are many other factors that also affect customer satisfaction and willingness to reuse, such as 
habits, expectation confirmation, etc. The data all come from online questionnaire surveys, which are affected by external factors such as difficulty in controlling the survey subjects. At the same time, the questionnaire survey samples are too small, resulting in inaccurate empirical analysis. It is recommended that there should be more variables in the later stage and increase the Korean sample to obtain comparative data between China and South Korea. At the same time, there should be more authoritative models to improve this research.

\section{References}

China Catering Big Data 2020. (2020). People Post Press.

Choi, H., and Choi, Y. (2011). The impact of smartphone application quality factors on trust and the users' continuance intention according to gender. Korea Society of Industrial Information Systems, 16(4), 151-162.

Cohen, J. (1988). Statistical power analysis for the behavioral sciences. Hillsdale, New Jersey: Lawrence Erlbaum Associates.

Engel, J., and Blackwell, R. (1982). Consumer behavior, 4thedition. Hinsdae, Lillinois, The Dryden Press, 321-326.

Hu, N., Chen, X., and Zhang, N. (2021). Influence of service quality of agricultural products e-commerce platform on customer loyalty - the mediating role of customer engagement. International Journal of Smart Business and Technology, 9(1), 13-28.

Jeon, P., Seo, K., and Hwang, S. (2019). A study on the influence of the perceived of service quality on the customer satisfaction and intention to rebuy in $\mathrm{O} 2 \mathrm{O}$ commerce. Journal of Distribution and Management Research, 22(4), 203-214.

Jin, Z., and Lim, C. (2020). A study on the influencing factors of customer satisfaction and continuous use intention in mobile payment service. International Journal of Smart Business and Technology, 8(2), 21-26.

Jung, S. (2016). A study on formation factors of O2O service loyalty: focusing on delivery service application. Department of Business Administration Graduate School of Soongsil University.

Kim, M. (2020). A study on the effect of the quality attributes of food service $\mathrm{O} 2 \mathrm{O}$ platform's on perceived value, customer satisfaction and continuous use intention. Korea Tourism Research Association, 34(1), 157-172. 
Lee, J. (2019). A study on the factors that influence the customer satisfaction and intent of continued use of the customers of food delivery services. General Management of Chung-Ang University.

Lee, O., Ryu, S., and Lee, M. (2019). A study on the influence of O2O service quality on perceived value, satisfaction, and intention to continue use. The Korea Society of Management information Systems, 274-280.

Lewis, R., and Booms, B. (1983). The marketing aspects of service quality. Emerging perspective on service marketing, 65(4), 99-107.

Oliver, R. (1981). Measurement and evaluation of satisfaction process in retail settings. Journal of Retailing, 57(3), 25-48.

Park, K., and Ha, H. (2012). Effects of e-service quality on satisfaction and site loyalty intention in online shopping malls - a comparison between open markets and individual shopping malls. The Journal of Business and Economics, 28(1), 103-138.

Park, W., Lee, S., Park, C., Jung, S., and Kim, H. (2021). The effect of service quality of internet insurance on intention to purchase online. International Journal of Smart Business and Technology, 9(1), 63-70.

Santos, J. (2003). E-service quality: a model of virtual service quality dimensions. Managing Service Quality, 13(3), 233-246.

Sun, J., and Lee, J. (2014). The effect of O2O characteristics on attractiveness, reliability and acceptance intention. Korean Association of Business Education, 12, 410-441.

$\mathrm{Wu}, \mathrm{Z}$. (2020). The impact of the $\mathrm{O} 2 \mathrm{O}$ food delivery service quality in china on intend to reuse: focused on the mediation effect of service satisfaction and consumer trust. Department of Business Administration of Mokpo National University.

Yang, Y. (2019). The changes and characteristics of the consciousness of quieting in the Late Korean Period-on the reality of the consciousness of Chinese Koreans. Haklim, 43, 5-32.

Zhang, Y., Zhang, L., and Kim, H. (2021). A study on the influencing factors of customer satisfaction and reuse intention: focused on $\mathrm{O} 2 \mathrm{O}$ delivery platform consumers of China. World Journal of Accounting, Finance and Engineering, 5(1). 